\title{
EXERGY AND EXERGOENVIRONMENTAL ASSESSMENT AND OPTIMIZATION OF LOW GWP REFRIGERANT FOR VAPOR COMPRESSION HEAT PUMP SYSTEM
}

\author{
Nyayu Aisyah ${ }^{1}$, Muhamad Idrus Alhamid ${ }^{1 *}$, Nasruddin ${ }^{1}$ \\ ${ }^{1}$ Department of Mechanical Engineering, Faculty of Engineering, Universitas Indonesia, Kampus UI \\ Depok, Depok 16424, Indonesia
}

(Received: July 2018 / Revised: August 2018 / Accepted: October 2018)

\begin{abstract}
Scientists have worked assiduously to find low GWP refrigerants for HVAC systems that specifically address the environmental problems of ozone depletion and global warming. $\mathrm{R} 1234 z e$ and R1234yf were considered as potential alternatives to conventional refrigerants such as R410A. Thermodynamic analysis of $4 \mathrm{~kW}$ air conditioning systems was conducted to assess system performance of R1234ze and R1234yf. Furthermore, exergy and exergo-environmental analysis were carried out for the heat pump system using selected environmentally friendly refrigerants. Finally, by using a multi-objective genetic algorithm, the optimum operating condition, including evaporation temperature, condensing temperature and mass flow refrigerant was determined. The result showed that the optimum operating condition of $20^{\circ} \mathrm{C}$ evaporation temperature, $42.57^{\circ} \mathrm{C}$ condensation temperature and $0.02 \mathrm{~kg} / \mathrm{s}$ mass flow rate, led to exergy efficiency of $51.92 \%$ and an exergo-environmental value of $101.925 \mathrm{mPts} / \mathrm{h}$. R1234ze has a comparable performance to R410A or performs even better.
\end{abstract}

Keywords: Exergo-environmental; Exergy; Heat pump; Low GWP refrigerants

\section{INTRODUCTION}

The search for alternative refrigerants has been, and still remains, a prevalent topic in the history of Heating Ventilating Air Conditioning systems (HVAC systems) (Mohd-Ghazali et al., 2011; Alhamid et al., 2013). Chlorofluorocarbon (CFC), as the first refrigerant used in HVAC systems was banned by the Montreal Protocol in 1987 to be replaced by Hydrofluorocarbon (HFC) and Hydrochlorofluorocarbon (HCFC). In 1996, the phase-out of CFC refrigerants was completed, and HFC and HCFC were recommended as CFC alternatives because of their low Ozone Depletion Potential (ODP). However, in 1990 it was found that both of these low ODP refrigerants actually contribute to the global warming phenomenon. Consequently, the Kyoto Protocol, issued in 1997, aimed to reduce global warming by decreasing greenhouse gases with the use of low Global Warming Potential (GWP) refrigerants (Yildirim et al., 2017).

Many alternative refrigerants were introduced to replace conventional refrigerants. For example, due to its low GWP value, low flammability, and comparable performance, the R1234 refrigerant series was widely touted as a potential alternative to replace the conventional refrigerant $\mathrm{R} 134 \mathrm{a}$ (Fukuda et al., 2014; Kondou \& Koyama, 2015; Nawaz et al., 2017; Wu et al., 2018).

\footnotetext{
*Corresponding author's email: mamak@eng.ui.ac.id, Tel. +62-21-7270032, Fax. +62-21-7270033 Permalink/DOI: https://doi.org/10.14716/ijtech.v9i6.2369
} 
$\mathrm{R} 32$ and L41a have also been recommended as candidates to replace R410A because not only do they have a low GWP value, but they also closely resemble the characteristics of R410A and perform well. (Alabdulkarem et al., 2015; Cho et al., 2016; Yildirim et al., 2017; Botticella et al., 2018; Cremaschi et al., 2018).

Recently, some researchers have shown interest in pursuing a return to natural refrigerants as alternative to commercial refrigerants. Nasruddin et al. (2018) conducted research using a working fluid mixture of $86 \%$ R601 and 14\% R744 for binary cycle systems. Yamaguchi et al. (2011) investigated the use of R744 for heat pump systems. Natural refrigerants such as hydrocarbons are considered non-toxic, non-flammable harmless working fluids, and furthermore, they do not contribute to global warming (Park et al., 2007; Sarkar \& Bhattacharyya, 2009; Mohanraj et al., 2009; Antunes \& Filho, 2016; Badache et al., 2018).

In order to ascertain whether an alternative refrigerant could be an option to replace conventional ones, a thermodynamic analysis is required. Park et al. (2007) conducted a thermodynamic analysis of a residential heat pump system using R433A as a replacement for HCFC22. R433A has zero ODP and a GWP of less than 5. The results revealed that the coefficient of performance for the system using R433A is $4.9 \%$ higher than a system using HCFC22. In conclusion, R433A is a good substitute for the conventional refrigerant has better performance (Park et al., 2007). Dopazo et al. (2009) also reported on the COP and exergy efficiency of a cooling system using alternative refrigerant R744 with an analysis and parametric study of the system. The result showed that the system has COP varied from 1.5-2.5 and can be increased $70 \%$ by doing optimization procedure. Nawaz et al. (2017) made a performance evaluation of a residential heat pump system in order to compare R600a and R290 refrigerants to HFC refrigerant, R134a. The analysis suggested that both refrigerants could be viable options with comparable performance (Nawaz et al., 2017).

But in previous literature that mentioned above, the analysis still not considers the effect of the system on the environment. So in this work, the exergoenvironmental analysis is discussed, and it becomes the novelty of this paper. The purpose of this work is to perform exergy and exergoenvironmental analyses of low GWP refrigerant R1234ze and R1234yf theoretically and compare it with R410A. After that, the multi-objective optimization is conducted by using the best refrigerant selected by exergy and exergoenvironmental analyses. From the result of the optimization procedure, the optimum condition including evaporation and condensation temperature, as well as the mass flow rate of refrigerant can be determined.

\section{WORKING FLUID AND SYSTEM MODELING}

\subsection{Fluid Properties}

Molés et al. (2014) identifies several criteria for selecting the working fluid in heat pump systems: thermo-physical properties, critical temperature and pressure, and the important environmental aspects of Ozone Depletion Potential (ODP) and Global Warming Potential (GWP). Table 1 and Figure 1 describe some refrigerants discussed in this study.

Table 1 Properties of discussed refrigerants

\begin{tabular}{lccc}
\hline \multicolumn{1}{c}{ Parameter } & R410 & R1234ze & R1234yf \\
\hline Critical Temp $\left({ }^{\circ} \mathrm{C}\right)$ & 71.3 & 153.7 & 94 \\
Critical Pressure $(\mathrm{MPa})$ & 4.90 & 3.97 & 3.34 \\
GWP & 2088 & 6 & 4 \\
Safety Group & A1 & A2L & A2L \\
Glide Temperature $\left({ }^{\circ} \mathrm{C}\right)$ & 0.2 & 0.2 & 0.2 \\
\hline
\end{tabular}

Source: Fukuda et al. (2014), Dai et al. (2015) 


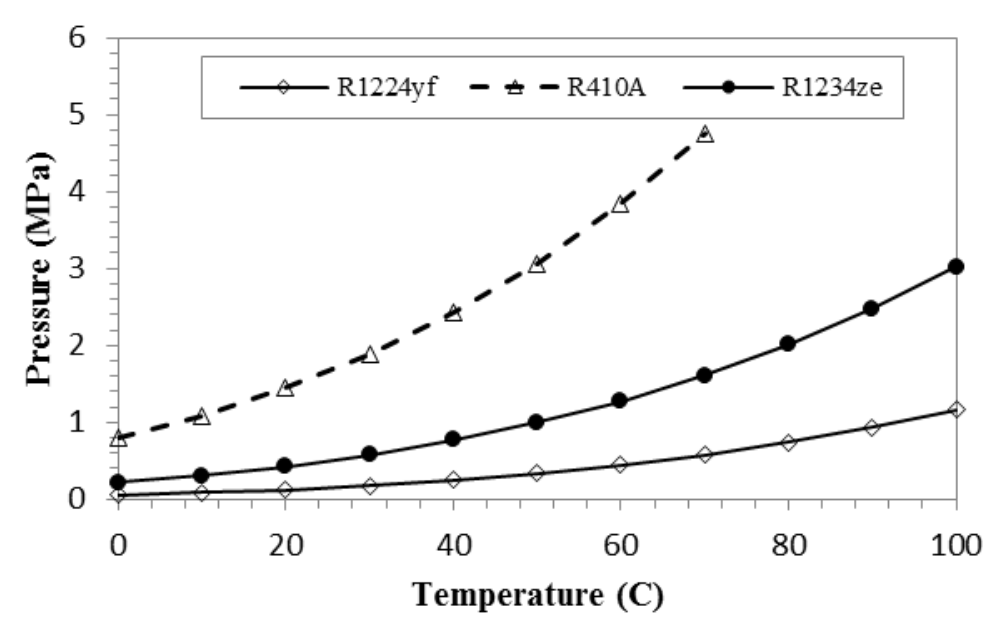

Figure 1 Temperature vs pressure of discussed refrigerants

Figure 1 shows that at the same temperature, both R1234ze and R1224yf have lower pressure than R410A, so both refrigerants could be selected as the alternative to R410A.

\subsection{Cycle Description}

A vapor compression heat pump cycle is shown in Figure 2. It consists of a compressor, a condenser, an expansion valve and an evaporator. External energy is supplied to the compressor, and heat is added to the system through an evaporator, while heat is rejected from the system through the condenser.

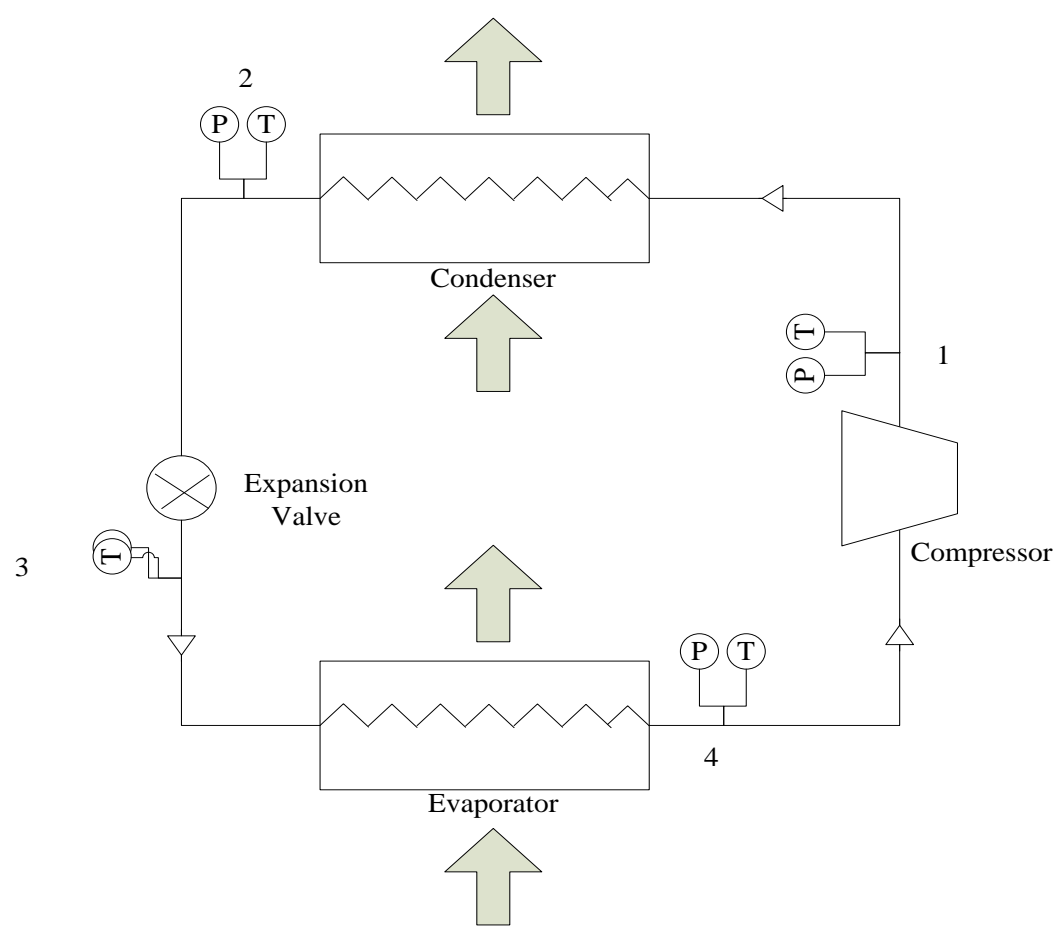

Figure 2 Heat pump system configuration

Working fluid enters the evaporator at a given temperature, then working fluid is converted to gas, absorbing heat from the air in the compartment. The working fluid exits the evaporator as saturated vapor and afterward enters the compressor. A working fluid with high temperature and pressure continues to the condenser which rejects heat into the environment. 


\subsection{Modeling of The System}

Thermal modeling includes mass and energy balances which are essential to improve system efficiency. In this study, a thermodynamic model is used to compare low GWP refrigerant R1234ze and R1234yf with R410A. Component modeling uses the following assumptions:

1) The system is under steady state conditions.

2) The pressure and heat loss in the pipelines of the system are not considered

3) Saturated refrigerant occurs at the exit of the evaporator and condenser.

4) The kinetic and potential energies are negligible.

Once all components of the cycles have been determined, the simulations were performed by using software MATLAB 2017b which also integrated with REFPROP ver. 9.0.

System performance analysis examines energy and exergy balances in the system components. Exergy is defined as the maximum available energy produced by a system or its surroundings. Therefore, exergy is the optimal use of energy, so exergy analysis should most certainly be investigated. The general forms of mass, energy, and exergy balance for each component in the system are as follows (Dincer et al., 2017):

$$
\sum \dot{\mathrm{m}}_{\mathrm{in}}=\sum \dot{\mathrm{m}}_{\mathrm{out}}
$$

While $\dot{m}$ is the mass flow rate and the subscripts in and out describe input and output. The first law of thermodynamics is written as:

$$
\mathrm{Q}_{\text {in }}+\dot{\mathrm{W}}_{\text {in }}+\dot{\mathrm{mh}}_{\mathrm{in}}=\mathrm{Q}_{\text {out }}+\dot{\mathrm{W}}_{\text {out }}+\dot{\mathrm{mh}}_{\text {out }}
$$

where $\mathrm{Q}$ is the heat transfer rate between control volume and the surroundings, $\dot{W}$ is the work rate, and $\mathrm{h}$ is the specific enthalpy. The energy efficiency of a heat pump system is indicated by its coefficient of performance (COP). COP is defined as the ratio of cooling capacity (total heat released through the condenser) to the total power consumption (total energy consumed by the compressor). The COP calculation can be expressed as follows:

$$
\mathrm{COP}=\frac{\mathrm{Q}_{\text {evap }}}{\dot{\mathrm{W}}_{\text {comp }}}
$$

The energy and exergy analysis are evaluated based on thermodynamic analysis, steady flow energy, and mass balance equations which are listed in Table 2.

Table 2 Calculation of thermodynamic analysis

\begin{tabular}{cll}
\hline Component & \multicolumn{1}{c}{ Energy } & \multicolumn{1}{c}{ Exergy destruction } \\
\hline $\mathrm{EV}$ & $\mathrm{Q}_{\mathrm{e}}=\mathrm{m}_{\mathrm{ref}}\left(\mathrm{h}_{1}-\mathrm{h}_{4}\right)$ & $\mathrm{Ex}_{\mathrm{e}}=\mathrm{m}_{\mathrm{ref}}\left(\mathrm{Ex}_{4}-\mathrm{Ex}_{1}\right)+\left[1-\left(\mathrm{T}_{\mathrm{a}}-\mathrm{T}_{\mathrm{cl}}\right)\right] \mathrm{Q}_{\mathrm{e}}$ \\
$\mathrm{CM}$ & $\mathrm{W}_{\mathrm{co}}=\mathrm{m}_{\mathrm{ref}}\left(\mathrm{h}_{2}-\mathrm{h}_{1}\right)$ & $\mathrm{Ex}_{\mathrm{co}}=\mathrm{W}_{\mathrm{co}}-\mathrm{m}_{\mathrm{ref}}\left(\mathrm{Ex}_{2}-\mathrm{Ex}_{1}\right)$ \\
$\mathrm{CD}$ & $\mathrm{Q}_{\mathrm{c}}=\mathrm{m}_{\mathrm{ref}}\left(\mathrm{h}_{2}-\mathrm{h}_{3}\right)$ & $\mathrm{Ex}_{\mathrm{c}}=\mathrm{m}_{\mathrm{ref}}\left(\mathrm{Ex}_{2}-\mathrm{Ex}_{3}\right)-\left[1-\left(\mathrm{T}_{\mathrm{a}}-\mathrm{T}_{\mathrm{c}}\right)\right] \mathrm{Q}_{\mathrm{c}}$ \\
$\mathrm{TV}$ & $\mathrm{h}_{3}=\mathrm{h}_{4}$ & $\mathrm{Ex}_{\mathrm{v}}=\mathrm{m}_{\mathrm{ref} ; \mathrm{LT}}\left(\mathrm{Ex}_{5}-\mathrm{Ex}_{6}\right)$ \\
\hline
\end{tabular}

Based on the first and second laws of thermodynamics, exergy analysis indicates the losses in the whole system and its components as listed in Table 2. In the vapor compression heat pump, the input exergy is the work of the compressor while the exergy of the product is the exergy of heat in the evaporator from the space to be cooled. The equation is given by:

$$
E x_{i n}=W_{c o}
$$

Finally, the exergy destruction and exergy efficiency can be calculated as follows: 


$$
\begin{aligned}
& E x_{D ; t o t}=E x_{e}+E x_{c o}+E x_{v} \\
& E x_{e f f}=1-\frac{E x_{D ; t o t}}{E x_{i n}}
\end{aligned}
$$

In addition, the exergo-environmental analysis are also carried out in this work. The equation that is used to determine the exergo-environmental value can be expressed as:

$$
\dot{\mathrm{B}}_{\mathrm{tot}, \mathrm{k}}=\dot{\mathrm{B}}_{\mathrm{D}, \mathrm{k}}+\dot{\mathrm{Y}}_{\mathrm{k}}
$$

where, $B_{\text {tot, } \mathrm{k}}$ is the total environmental impact, and $\mathrm{B}_{\mathrm{D}, \mathrm{K}}$ is the environmental impact related to exergy destruction on each component of the system. $\mathrm{B}_{\mathrm{DK}}$ is calculated by using the equation as follows:

$$
\dot{\mathrm{B}}_{\mathrm{D}, \mathrm{k}}=\mathrm{b}_{\mathrm{F}, \mathrm{k}} \dot{\mathrm{E}}_{\mathrm{D}, \mathrm{k}}
$$

where, $\mathrm{B}_{\mathrm{tot}, \mathrm{K}}$ is environmental eco-indicator and $\mathrm{E}_{\mathrm{D}, \mathrm{K}}$ is the exergy destruction.

\section{RESULTS AND DISCUSSION}

\subsection{Evaluation of Working Fluid}

The evaluation of the refrigerant was conducted by considering the physical properties and environmental effect. There were two candidates, namely R1234ze and R1234yf to replace R410A. Besides considering the thermophsical properties of refrigerants, some parameters such as Global Warming Potential (GWP) and safety group of refrigerants were accounted for. Figure 3 shows the result of the refrigerant evaluation from five parameters including critical temperature, critical pressure, GWP, safety group, and glide temperature.

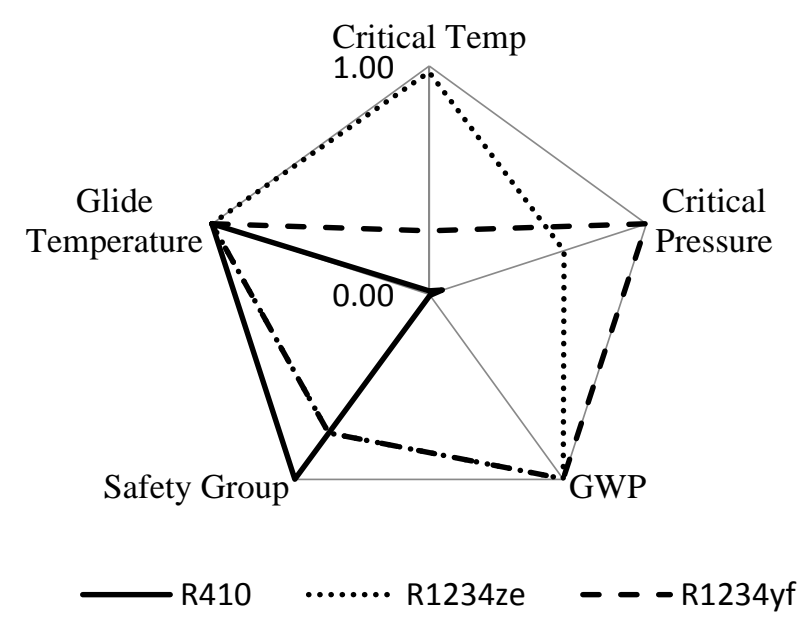

Figure 3 Evaluation of physical properties of some refrigerants using a spider plot

From Figure 3, it can be concluded that both R1234ze and R1234yf have perfect criterion as an environmentally friendly replacement refrigerant. In addition, a Total Equivalent Warming Impact (TEWI) analysis was also performed in order to investigate the effect of using R1234ze, R1234yf and R410A as the refrigerant in a heat pump system. Figure 4 shows the result of the TEWI analysis.

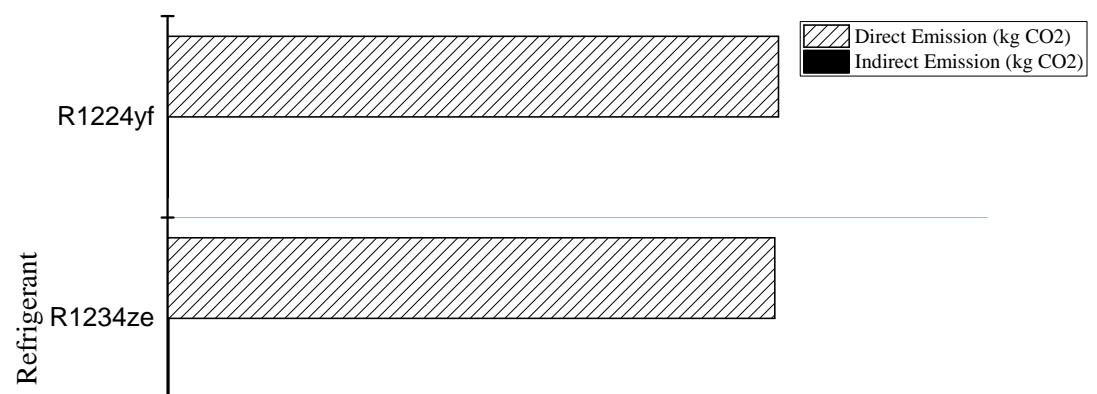


Figure 4 TEWI of refrigerants in regard to environmental effects

TEWI is an index that is used to compare the global warming effects of alternative refrigeration systems because it consists of contributions from the refrigerant, cooling efficiency, and weight. TEWI is divided into two types, indirect emission and direct emission. Figure 4 demonstrates that $\mathrm{R} 410 \mathrm{~A}$ has the highest value both of indirect emission and direct emission of $\mathrm{CO}_{2}$. It has about $900 \mathrm{kgCO}_{2}$ for indirect emission and about $400 \mathrm{kgCO}_{2}$ for direct emission. Thus, both low GWP refrigerants, R1234ze and R1234yf have the lowest impact for the environment. They have about $700 \mathrm{~kg} \mathrm{CO} 2$ indirect emission, but virtually zero $\mathrm{kgCO}_{2}$ for direct emission.

\subsection{Exergy Analysis}

Table 3 and Figure 5 represent the exergy destruction total of four main components and efficiency of the system.

Table 3 Exergy efficiency for each component of the system

\begin{tabular}{lccc}
\hline Component & R1234ze & R1234yf & R410A \\
\hline Compressor & 67.29 & 68.14 & 70.67 \\
Condenser & 99 & 99 & 99 \\
Exp Valve & 82.18 & 86.18 & 92 \\
Evaporator & 98.26 & 98 & 98 \\
\hline \multicolumn{1}{c}{ Total } & 49.75 & 48.80 & 48.20 \\
\hline
\end{tabular}

According to Table 3, R1234ze has the highest Exergy Efficiency compared to R1234yf and $\mathrm{R} 410 \mathrm{~A}$. In order to know the inefficiencies that could occur on the system components, the exergy destruction was determined. As shown in Figure 5, the compressor is responsible for the highest exergy destruction, followed by the evaporator, expansion valve and condenser. It is obvious that the compressor has the highest amount of exergy destruction. The heat loss is due to electrical, mechanical, and isentropic efficiency. The exergy destruction is about 265 Watts or $70 \%$ while other high exergy destruction occurs in the expansion valve, followed by evaporator. The loss in the evaporator is partly due to the rise in temperature at the end of the evaporation process which leads to a temperature difference in the heat transfer process that is expelled into the environment. 


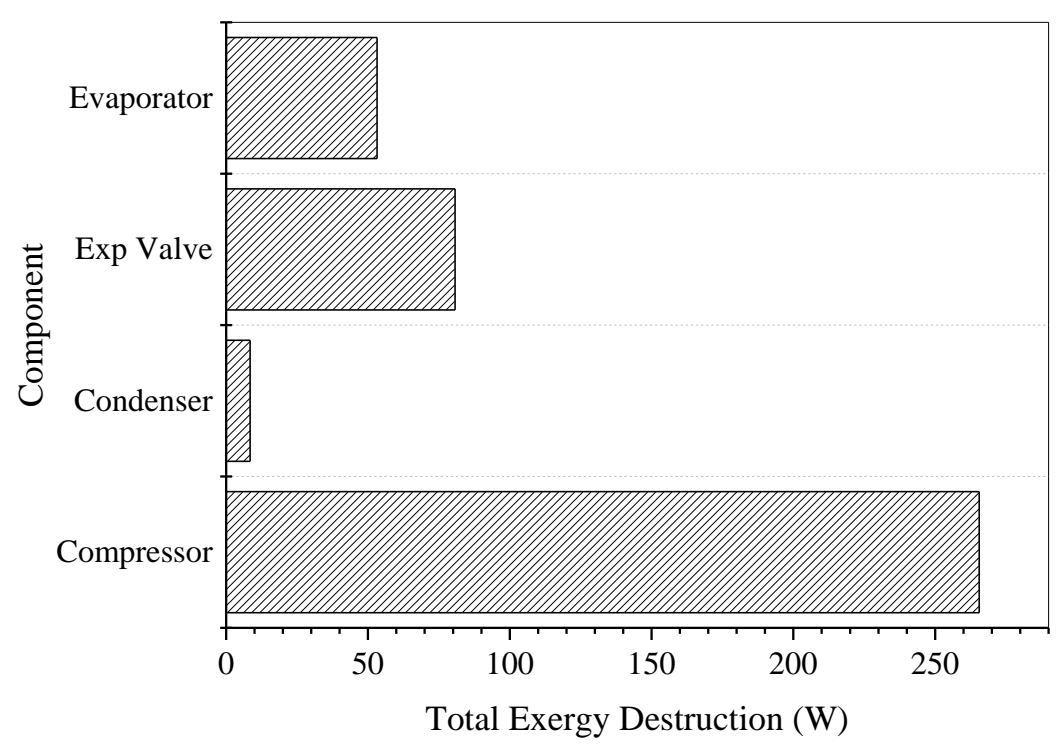

Figure 5 Total exergy destruction on each component

\subsection{Exergo-environmental Analysis}

Exergo-environmental analysis demonstrates the environmental impact associated with an energy conversion system. Exergo-environmental analysis results are listed in Table 4.

Table 4 Exergo-environmental results

\begin{tabular}{lrrr}
\hline Component & R1234ze & R1234yf & R410A \\
\hline Compressor & 424.942 & 358.894 & 473.336 \\
Condenser & 13.739 & 8.822 & 69.204 \\
Exp Valve & 125.970 & 131.335 & 183.740 \\
Evaporator & 85.560 & 72.606 & 110.068 \\
\hline
\end{tabular}

From Table 4, it clear that the compressor has the highest values of component related environmental impact. The same trend is also shown in exergy destruction analysis. Higher exergy destruction indicates higher exergo-environmental impact. And it means that decreasing the exergy destruction will lead to a decrease in the environmental impact. Table 4 also shows that R410A has the highest environmental impact, while R1234ze and R1234yf have comparable exergo-environmental results.

\subsection{Multi-objective Genetic Algorithm Optimization Result}

The optimization scenario is performed by using a multi-objective genetic algorithm. The objective function of the system is exergy efficiency and exergo-environmental value, while the constraints are the evaporation temperature, the condensation temperature and the mass flow rate. Based on an evaluation of refrigerants using spider plot thermophysical properties, the TEWI analysis method, exergy analysis, and exergo-environmental analysis, it is clear that the best refrigerant to replace R410A is R1234ze. Consequently, in the optimization procedure, R1234ze refrigerant was utilized.

Figure 6 shows the Pareto Front which is a result of a multi-objective genetic algorithm optimization. Due to so many optimum points offered by the Pareto front as illustrated in Figure 6 and the difficulties to choose the optimum if both exergy and exergo-environmental are considered, a selection of a single optimum points were needed. The existing points on the Pareto front, as illustrated in Figure 6, require a decision-making process. 


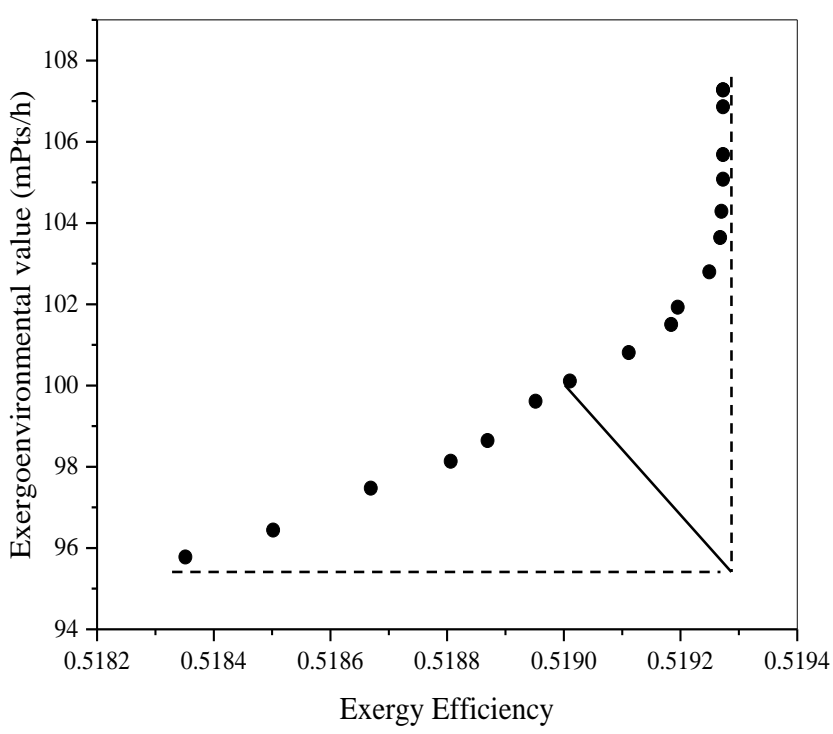

Figure 6 Pareto front optimization result

In this study, the most common type of decision-making method, TOPSIS (Technique for Order Preference by Similarity to an Ideal Solution) was selected. The TOPSIS method is one of the best methods for selecting the optimum value from a number of optimum solutions. The optimum point is chosen by selecting the point farthest to the non-ideal point and the point that is closest to the ideal point (Nasruddin et al., 2017). Table 5 gives information about the optimum point selected by using the TOPSIS method. Based on the optimization using the multi-objective genetic algorithm, the optimum exergy efficiency and exergo-environmental value has an evaporation temperature of $20^{\circ} \mathrm{C}$, a condensation temperature of $42.57^{\circ} \mathrm{C}$ and a mass flow rate refrigerant of $0.02 \mathrm{~kg} / \mathrm{s}$.

Table 5 Optimum point of view from Pareto Front

\begin{tabular}{|c|c|}
\hline Parameter & Multi-objective Optimum Point \\
\hline $\mathrm{T}_{\text {evap }}(\mathrm{C})$ & 20 \\
\hline $\mathrm{T}_{\text {cond }}(\mathrm{C})$ & 42.57 \\
\hline $\mathrm{m}_{\mathrm{ref}}(\mathrm{kg} / \mathrm{s})$ & 0.02 \\
\hline \multicolumn{2}{|l|}{ Results } \\
\hline Exergy Efficiency (\%) & 51.92 \\
\hline Exergoenvironmental (mPts/h) & 101.925 \\
\hline
\end{tabular}

\section{CONCLUSION}

Exergy and exergo-environmental analysis and optimization were conducted in this study. The refrigerant R1234ze was chosen based on the evaluation of its thermophysical properties, the TEWI analysis method, and exergy and exergo-environmental analyses. After conducting this analysis, an optimization procedure was performed. By using a multivariable genetic algorithm, the system was optimized. In the optimization procedure, the exergy efficiency and exergoenvironmental were choosen as the objective functions, while evaporating temperature, condensing temperature, and refrigerant mass flow rate were selected as constraints. The results showed that the heat pump system using environmentally friendly refrigerant R1234ze has a good performance with an exergy efficiency of $51.92 \%$ and a $101.925 \mathrm{mPts} / \mathrm{h}$ exergo-environmental 
value with an evaporating temperature of $20^{\circ} \mathrm{C}$, a condensing temperature of $42.57^{\circ} \mathrm{C}$, and a mass flow rate of $0.02 \mathrm{~kg} / \mathrm{s}$.

\section{ACKNOWLEDGEMENT}

The authors gratefully acknowledge Universitas Indonesia for supporting this research under the Tugas Akhir Mahasiswa Doktor (TADOK) research grant 2018 number 1356/UN2.R3.1/HKP.05.00/2018 dated March 21, 2018.

\section{REFERENCES}

Alabdulkarem, A., Eldeeb, R., Hwang, Y., Aute, V., Radermacher, R., 2015. Testing, Simulation and Soft-optimization of R410A Low-GWP Alternatives in Heat Pump System. International Journal of Refrigeration, Volume 60, pp. 106-117

Alhamid, M.I., Nasruddin, Darwin, R.B.S., Lubis, A., 2013. Characteristics and COP Cascade Refrigeration System using Hydrocarbon Refrigerant (Propane, Ethane and $\mathrm{CO}_{2}$ ) at Low Temperature Circuit (TC). International Journal of Technology, Volume 4(2), pp. 112-120

Antunes, A.H.P., Filho, E.P.B., 2016. Experimental Investigation on the Performance and Global Environmental Impact of a Refrigeration System Retrofitted with Alternative Refrigerants. International Journal of Refrigeration, Volume 70, pp. 119-127

Badache, M., Ouzzane, M., Eslami-Nejad, P., Aidoun, Z., 2018. Experimental Study of a Carbon Dioxide Direct-expansion Ground Source Heat Pump ( $\mathrm{CO}_{2}$-DX-GSHP). Applied Thermal Engineering, Volume 130, pp. 1480-1488

Botticella, F., de Rossi, F., Mauro, A.W., Vanoli, G.P., Viscito, L., 2018. Multi-criteria (Thermodynamic, Economic and Environmental) Analysis of Possible Design Options for Residential Heating Split Systems Working with Low GWP Refrigerants. International Journal of Refrigeration, Volume 87, pp. 131-153

Cho, I.Y., Seo, H.J., Kim, D., Kim, Y., 2016. Performance Comparison between R410A and R32 Multi-heat Pumps with Sub-cooler Vapor Injection in the Heating and Cooling Modes. Energy, Volume 112, pp. 179-187

Cremaschi, L., Yatim, A.S., Mulugurthi, S.K., 2018. Experimental Study of Oil Retention in Microchannel Type Evaporators of Air-source Heat Pump Systems. International Journal of Refrigeration, Volume 91, pp. 158-166

Dai, B., Dang, C., Li, M., Tian, H., Ma, Y., 2015. Thermodynamic Performance Assessment of Carbon Dioxide Blends with Low-Global Warming Potential (GWP) Working Fluids for a Heat Pump Water Heater. International Journal of Refrigeration, Volume 56, pp. 1-14

Dincer, I., Rosen, M.A., Ahmadi, P., 2017. Optimization of Energy Systems. John Wiley \& Sons Ltd., USA

Dopazo, J.A., Fernández-Seara, J., Sieres, J., Uhía, F.J., 2009. Theoretical Analysis of $\mathrm{CO}_{2}-\mathrm{NH}_{3}$ Cascade Refrigeration System for Cooling Applications at Low Temperatures. Applied Thermal Engineering, Volume 29(8-9), pp. 1577-1583

Fukuda, S., Kondou, C., Takata, N., Koyama, S., 2014. Low GWP Refrigerants R1234ze(E) and R1234ze(Z) for High Temperature Heat Pumps. International Journal of Refrigeration, Volume 40, pp. 161-173

Kondou, C., Koyama, S., 2015. Thermodynamic Assessment of High-temperature Heat Pumps using Low-GWP HFO Refrigerants for Heat Recovery. International Journal of Refrigeration, Volume 53, pp. 126-141

Mohanraj, M., Jayaraj, S., Muraleedharan, C., 2009. Environment Friendly Alternatives to Halogenated Refrigerants-A Review. International Journal of Greenhouse Gas Control, Volume 3(1), pp. 108-119 
Mohd-Ghazali, N., Anwar, M., Settar, N.H.M.A., 2011. Thermoacoustic Cooling with No Refrigerant. International Journal of Technology, Volume 2(3), pp 234-241

Molés, F., Navarro-Esbri, J., Peris, B., Mota-Babiloni, A., Barragán-Cervera, Á., 2014. Theoretical Energy Performance Evaluation of Different Single Stage Vapour Compression Refrigeration Configurations using R1234yf and R1234ze(E) as Working Fluids. International Journal of Refrigeration, Volume 44, pp. 141-150

Nasruddin, Nasution, S., Aisyah, N., Surachman, A., Wibowo, A.S., 2018. Exergy Analysis and Exergoeconomic Optimization of a Binary Cycle System using Multi Objective Genetic Algorithm. International Journal of Technology, Volume 9(2), pp. 275-286

Nasruddin, Alhamid, M.I., Aisyah, N., 2017. Energetic, Economic and Environmental (3E) Optimization of Solar Assisted Heat Pump using Low GWP Refrigerant R1234ze(E) for High Temperature Application. In: $3^{\text {rd }}$ International Conference on Power Generation Systems and Renewable Energy Technologies (PGSRET), Johor Bahru, 4-6 April, Malaysia, pp. 79-84

Nawaz, K., Shen, B., Elatar, A., Baxter, V., Abdelaziz, O., 2017. R1234yf and R1234ze(E) as Low-GWP Refrigerants for Residential Heat Pump Water Heaters. International Journal of Refrigeration, Volume 82, pp. 348-365

Park, K.J., Seo, T., Jung, D., 2007. Performance of Alternative Refrigerants for Residential AirConditioning Applications. Applied Energy, Volume 84(10), pp. 985-991

Sarkar, J., Bhattacharyya, S., 2009. Assessment of Blends of $\mathrm{CO}_{2}$ with Butane and Isobutane as Working Fluids for Heat Pump Applications. International Journal of Thermal Sciences, Volume 48(7), pp. 1460-1465

Wu, D., Hu, B., Wang, R.Z., 2018. Performance Simulation and Exergy Analysis of a Hybrid Source Heat Pump System with Low GWP Refrigerants. Renewable Energy, Volume 116(Part A), pp. 775-785

Yildirim, C., Özkan, D.B., Onan, C., 2017. Theoretical Study of R32 to Replace R410A in Variable Refrigerant Flow Systems. International Journal of Ambient Energy, Volume 39(1), pp. 87-92

Yamaguchi, S., Kato, D., Saito, K., Kawai, S., 2011. Development and Validation of Static Simulation Model for $\mathrm{CO}_{2}$ Heat Pump. International Journal of Heat and Mass Transfer, Volume 54(9-10), pp. 1896-1906 